\title{
Diversidade e livre pensamento
}

Arte, antropologia, estética, literatura, história, ciências sociais, sem hierarquias, são disciplinas que encontram no universo das chamadas culturas populares matéria prima para a reflexão sobre a realidade social. Os artigos apresentados no presente volume da revista Textos Escolhidos de Cultura e Arte Populares são testemunhos disto. Aqui reunidos, em sua totalidade, expressam a condição de livre pensamento que deve presidir a produção de conhecimento nos tempos mutantes da atualidade, quando as mais diferentes concepções de mundo e as práticas que delas decorrem se firmam, lado a lado, expressando a diversidade da vida e a relatividade das verdades absolutas.

São muitos os campos abordados: literatura oral, música, festa, ritual, dança, pensamento social, folclore, artes visuais, estética, artesanato, religião, patrimônio imaterial, identidade. Um riquíssimo repertório de saberes e de expressões culturais em sua maioria referidos à realidade brasileira, mas que, rompendo fronteiras, também alcançam lugares distantes como México, Portugal e Xangai.

Ricardo LIma [co-editor] 